\title{
SCHOOL, COMPANY AND MUNICIPALITY COLLABORATION IN CAREER EDUCATION
}

Gunārs Strods

Rezekne Higher Educational Institution

\begin{abstract}
This article presents results of implementation of school, company and municipality collaboration model in career education in Latvia. The purpose of the study was to work out and implement an educational model for facilitation of student career choice and learning for working life in general education. Empirical data were collected through student selfassessment questionnaires, student portfolio evaluation and analysis of career counselor's interview. Data collected in period from September, 2012 till February, 2013. 969 students and 19 counselors were involved in the study. Results indicate positive correlation between student's future plans and quality of career management skills portfolio. For integration of career education in school learning process career counselor, class teacher and subject teacher collaboration is necessary.
\end{abstract}

Key words: career guidance, career education, general education

Latvian society experienced economic crisis in last five years and, as other European countries, tray to find an effective way how to solve problems. "Europe faces a number of challenges that can only be met if it has innovative, well-educated, and entrepreneurial citizens who, whatever their walk of life, have the spirit and inquisitiveness to think in new ways, and the courage to meet and adapt to the challenges facing them" (Education, Audiovisual and Culture Executive Agency, 2012). Dynamic economy demanded information and knowledge, but have simultaneously required considerable adjustments in the skills required and in working patterns. The society of the future will be a learning society. In light of this, it is evident that education systems, primarily the education of teachers and of those involved in training, have a central role to play (European Commission, 2001, 2010; Faure, 1972). Important challenge relates to the need to further support the integration of the transversal skills such as ICT, entrepreneurship and civics into the teaching and learning process (European Commission/EACEA/Eurydice, 2012).

For implementation of lifelong learning European Council considering that:

"Citizens' lives are increasingly characterised by multiple transitions: notably from school to vocational education and training (VET), higher education or employment, or from employment to unemployment, further training or departure from the labour market. Guidance plays a decisive role in the major decisions that individuals have to take throughout their lives. In this respect, it can contribute to empowering individuals to manage their own career paths in a more secure way in the context of today's labour market, and to achieve a better balance between their personal and professional lives"; 
- Encourage coordination and cooperation among the various national, regional and local stakeholders in lifelong guidance" (Education, Youth and Culture Council of the European Union, 2008).

Latvian Career guidance and counseling system provide information, career counseling and career education. One of main task for career guidance is encourage the lifelong career management skills development. Career management skills are integrated into subject standards as learning outcomes. National education standards determine that one of the main goals of education is to prepare students to make a conscious career choice (Latvian State Education Development Agency, 2012).

In period from January 3, 2011 till December 31, 2013 seven universities , 15 municipalities and five non - govermental organizations realize European Social Fund Project "Development and implementation of the support programs for establishing the support system for the young people under the exclusion risk" (Agreement Nr.2010/0328/1DP/1.2.2.4.1/10/IPIA/VIAA/002). The aim of the project is to explore, model, approbate and evaluate the system of decreasing and preventing the risk of social exclusion for young people aged 13 - 25 of five regions in 15 municipalities and 25 schools in order to decrease the social exclusion risks and the number of those young people who are early dropout's of education and stay out of education as well as to promote their vocationallyoriented education and employment by strengthening the capacity of involved institutions, developing the support system and increasing the competence level of the personnel involved in the project (Atbalsta programmu izstrāde un īstenošana sociālās atstumtības riskam pakḷauto jauniešu atbalsta sistēmas izveidei, 2011).

One of project activities is "Career education program in schools". Objective of program is facilitation of students (13-25 years old) career choice and learning for working life. Schools voluntary participated in career education program. Main idea of program is implementation of school, company and municipality collaboration model in career education.

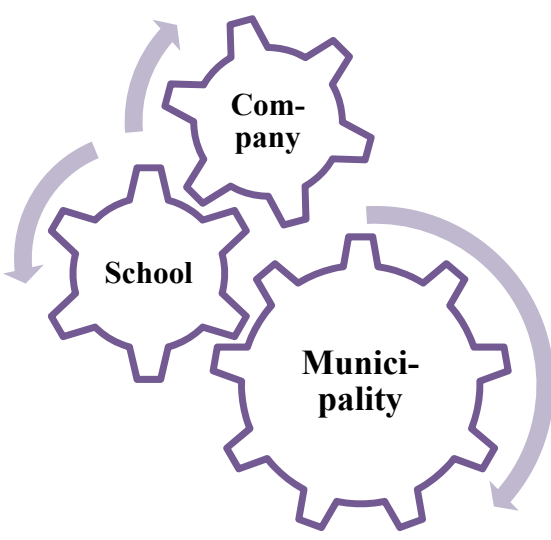

Figure 1. Idea of school, company and municipality collaboration model in career education 
Were a three interrelated stages of implementation of model - career education, career counseling and case management.

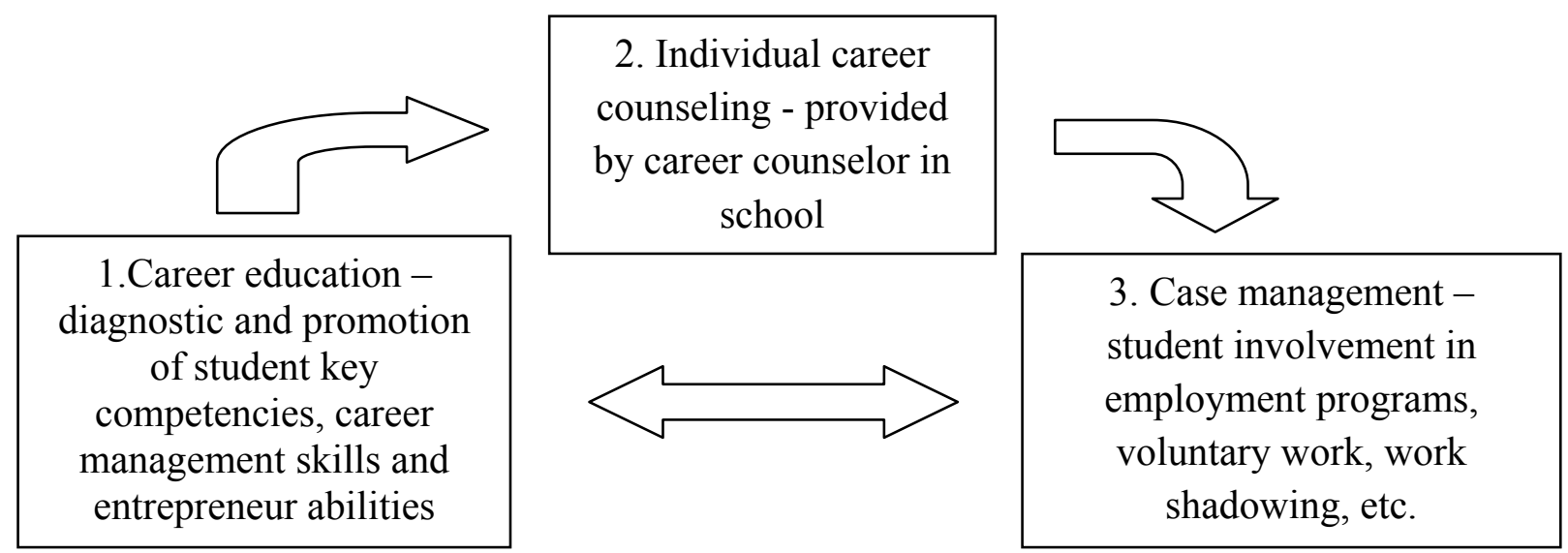

\section{Figure 2. Scheme of career education program implementation stages $I^{\text {st }}$ stage. Career education}

Career education is planed process of educational activities with aim to support student skills development, interests and provide career goals setting opportunities; introduction with connection between labour market and education; career planning and employability. Project schools in collaboration with municipality and parents invite for collaboration companies. Companies participate voluntary without financial benefits. Collaboration with companies based on "two-way process: an opportunity for young people to acquaint themselves with the world of work as well as an opportunity for employers to familiarise themselves with the local talent pool...it is important that employers, especially small and medium-sized enterprises (SMEs), are given the necessary support to be able to offer apprenticeships and traineeships" (CEDEFOP, 2010). Career education program is preventive and holistic and involve all students. Career education should provide for students both - perspective of employee and employer. Students are involved in longitudinal career education process and have an opportunity practicing key competences and career management skills and develop entrepreneur abilities. Key competencies are a basement for career management skills and entrepreneur abilities. Entrepreneur abilities grow up when individual career management skills are developed. Links between key competencies, career management skills and entrepreneur abilities explored in figure 3. 


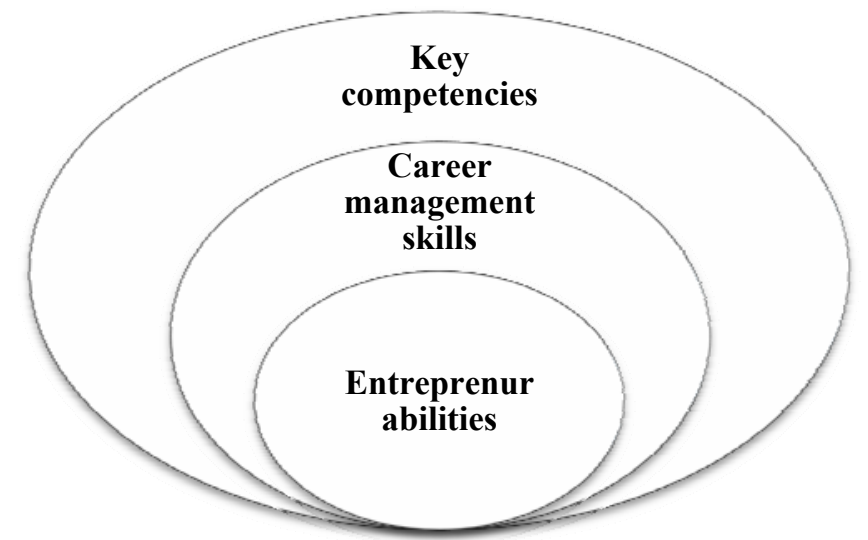

Figure 3. Links between key competencies, career management skills and entrepreneur abilities

The acquisition and development of eight key competences is included in career education program:

- communication in the mother tongue, which is the ability to express and interpret concepts, thoughts, feelings, facts and opinions in both oral and written form (listening, speaking, reading and writing) and to interact linguistically in an appropriate and creative way in a full range of societal and cultural contexts;

- communication in foreign languages, which involves, in addition to the main skill dimensions of communication in the mother tongue, mediation and intercultural understanding. The level of proficiency depends on several factors and the capacity for listening, speaking, reading and writing;

- mathematical competence and basic competences in science and technology. Mathematical competence is the ability to develop and apply mathematical thinking in order to solve a range of problems in everyday situations, with the emphasis being placed on process, activity and knowledge. Basic competences in science and technology refer to the mastery, use and application of knowledge and methodologies that explain the natural world. These involve an understanding of the changes caused by human activity and the responsibility of each individual as a citizen;

- digital competence involves the confident and critical use of information society technology (IST) and thus basic skills in information and communication technology (ICT);

- learning to learn is related to learning, the ability to pursue and organise one's own learning, either individually or in groups, in accordance with one's own needs, and awareness of methods and opportunities;

- social and civic competences. Social competence refers to personal, interpersonal and intercultural competence and all forms of behaviour that equip individuals to participate in an effective and constructive way in social and working life. It is linked to personal and social well-being. An understanding of codes of conduct and customs in the different environments in which individuals operate is essential. Civic competence, and particularly 
knowledge of social and political concepts and structures (democracy, justice, equality, citizenship and civil rights), equips individuals to engage in active and democratic participation;

- sense of initiative and entrepreneurship is the ability to turn ideas into action. It involves creativity, innovation and risk-taking, as well as the ability to plan and manage projects in order to achieve objectives. The individual is aware of the context of his/her work and is able to seize opportunities that arise. It is the foundation for acquiring more specific skills and knowledge needed by those establishing or contributing to social or commercial activity. This should include awareness of ethical values and promote good governance;

- cultural awareness and expression, which involves appreciation of the importance of the creative expression of ideas, experiences and emotions in a range of media (music, performing arts, literature and the visual arts) (The European Parliament and the Council of the European Union, 2006).

Career management skills have not common definition in different countries. Such skills, which should be maintained throughout life, are based on key competences, in particular 'learning to learn', social and civic competences including intercultural competences - and a sense of initiative and entrepreneurship (Education, Youth and Culture Council of the European Union, 2008).

According to the Key Competence Framework, the entrepreneurship key competence refers to an individual's ability to turn ideas into action. It includes creativity, innovation and risk taking, as well as the ability to plan and manage projects in order to achieve objectives (Education, Audiovisual and Culture Executive Agency, 2012).

Each school have a 1- 3 partner companies. For each company school delegate one class for collaboration during the year. School provide resources for career education program implementation. Company representatives lead two seminars at school and receive two visits at company. Company representatives are the experts in student's projects development and evaluation. Company provide resources for project's development when it's possible. The main objectives for students are as follows:

- To develop lifelong learning key competencies, career management skills and entrepreneur abilities;

- To put theoretical knowledge in practice;

- To get to know the labour environment;

- To verify choice of career;

- To get assistance in taking decisions and motivation to continue further education/training;

- To build networks and present themselves positively to potential future employers;

- To prepare digital portfolio of career management skills. 
During the school year students reflect on collaboration with company and their own skills development (Strods, 2003, 2006, 2012). Each month students has specific topic in portfolio:

September - "Me and my career perspective"; October - "My career management skills and portfolio"; November - "My investigation on professions"; December - "My visit to company"; January - "My presentation skills"; February - "My innovative ideas"; March - "My decision making skills"; April - "My contribution to class project"; May - "My evaluation of collaboration with company".

$2^{\text {nd }}$ stage. Career counseling

Municipality authorizes a career counselor to coordinate career education in school and collaboration with company. Career counselor led one group counseling session per month in each involved class. Aim of group counseling was introduce the students with task for individual portfolio and resources for career education. A counselor prepared materials for class teacher and subject teachers according to tasks for career education. At least one hour per week counselor did individual counseling for students according portfolio topics and other career related questions.

$3^{\text {rd }}$ stage. Case management

Municipality and company organize employment programs for students in summer. Students under social exclusion risk, talented and very motivated students can be selected for participation in employment programs. Selection should be done on portfolio evaluation and assessment of social exclusion risk. Career counselor in collaboration with municipality specialists and company representatives provide case management for selected students. Case management is based on long-term support of student career needs of ensuring the involvement of non-school partners and mentors. A professional career counselor, external experts, volunteer mentors and student cooperation should be established in implementation of individualized guidance plan.

This research was designed to evaluate career education program for promotion of student career management skills and explore relationships between career guidance and student career management skills development.

This study uses both quantitative and qualitative approaches in a concurrent mixed methods design (Teddlie \& Tashakkori, 2006). Student's self-assessment and portfolio quality assessment data were collected from students who participated in school, company and municipality collaboration in career education pilot project. Students from seven, eighth, ten and eleven grades were involved in career education pilot project. Last year students from basic and secondary schools were not involved in pilot project.

Data was collected between September, 2012 and February, 2013. Each month students complete individual and in small groups tasks and reflect on their action in digital portfolio. Students upload digital portfolio to internet classroom at the end of month. Career counselors each month collect quantitative data of groups 
and individual career counseling and evaluate student's portfolio quality. All students completed a self-assessment questionnaire about their future plans after school graduate. Career counselors each month wrote evaluation reports of group and individual counseling sessions. Career counselors interviewed at February using a structured interview format.

A total of 969 (438 female and 531 male) students between the ages of 13 and 25 participated in the study. Nineteen career counselors participated in interviews. All participants were introduced to the purpose of study.

In September, 2012 all students completed a self-assessment questionnaire about their future plans after school graduate. Results of questionnaire presented in Table 1.

Table 1

Student's future plans after school graduate at the beginning of school year

\begin{tabular}{llcccc}
\hline \hline & & & & Cumulative \\
\hline Valid & I did not think about it yet & 215 & 22,2 & 23,0 & 23,0 \\
& I don't know yet & 242 & 25,0 & 25,9 & 48,8 \\
& I have a several choices & 91 & 9,4 & 9,7 & 58,5 \\
& I have a two choices & 140 & 14,4 & 15,0 & 73,5 \\
& I clearly know what I'll do & 248 & 25,6 & 26,5 & 100,0 \\
& Total & 936 & 96,6 & 100,0 & \\
Missing & System & 33 & 3,4 & & \\
Total & 969 & 100,0 & & \\
\hline \hline
\end{tabular}

Results show that $22,2 \%$ of students did not think about future plans and $25 \%$ don't know what they do after graduate school. Results evidence for career guidance in school is necessary.

To explore relationships between student's future plans and their career management skills a data of quality of portfolio and future plans questionnaire was examined. Quality of student's career management portfolio was evaluated by criteria:

- tasks not completed, portfolio not uploaded and student did not log in into internet classroom -0 points;

- tasks not completed, portfolio not uploaded, but student was log in into internet classroom - 1point;

- tasks partly completed, delay to upload portfolio - 2 points;

- tasks partly completed, portfolio uploaded in time - 3 points;

- tasks completed, portfolio uploaded in time - 4 points;

- student did more than task demanded but delay to upload portfolio - 5 points;

- student did more than task demanded and portfolio uploaded in time -6 points. 
The Pearson correlation between student's future plans and quality of career management skills portfolio are presented in Table 2.

Table 2

Pearson correlation between student's future plans and quality of career management skills portfolio

\begin{tabular}{cccc}
\hline \hline & & $\begin{array}{c}\text { Student's } \\
\text { future plans } \\
09.2012 .\end{array}$ & $\begin{array}{c}\text { Quality of career } \\
\text { management skills } \\
\text { portfolio 09.2012. }\end{array}$ \\
\hline Student's future plans & Pearson Correlation & 1 &, $346^{* * *}$ \\
09.2012. & Sig. (2-tailed) & &, 000 \\
Quality of career & Pearson Correlation &, $346^{* *}$ & 936 \\
management skills & Sig. (2-tailed) &, 000 & 1 \\
portfolio 09.2012. & $\mathrm{N}$ & 936 & 965 \\
\hline \hline
\end{tabular}

**. Correlation is significant at the 0.01 level (2-tailed).

Results in table 2 show positive correlation between student's future plans and quality of career management skills portfolio $(\mathrm{r}=, 346)$. These results prove the idea of using portfolio in career education. Portfolio quality indicated a level of student career management skills. Student's portfolio quality was compared month by month. Results of student's career management skills portfolio quality evaluation presented in Table 3.

Table 3

Descriptive statistics of student's career management skills portfolio quality evaluation

\begin{tabular}{cccccccc}
\hline \hline & $\begin{array}{c}\text { Portfolio } \\
\text { quality }\end{array}$ & $\begin{array}{c}\text { Portfolio } \\
\text { quality }\end{array}$ & $\begin{array}{c}\text { Portfolio } \\
\text { quality }\end{array}$ & $\begin{array}{c}\text { Portfolio } \\
\text { quality }\end{array}$ & $\begin{array}{c}\text { Portfolio } \\
\text { quality }\end{array}$ & $\begin{array}{c}\text { Portfolio } \\
\text { quality }\end{array}$ \\
& 09.2012. & 10.2012. & 11.2012. & 12.2012. & 01.2013. & 02.2013. \\
\hline $\mathrm{N}$ & 965 & 910 & 861 & 741 & 740 & 466 \\
& Valid & 4 & 59 & 108 & 228 & 229 & 503 \\
& Missing & 2,19 & 1,79 & 1,95 & 1,91 & 2,14 & 2,19 \\
Mean & 2,00 & 2,00 & 2,00 & 2,00 & 3,00 & 3,00 \\
Median & 2 & 0 & 0 & 0 & 0 & 0 \\
Mode & 1,428 & 1,465 & 1,694 & 1,480 & 1,709 & 1,692 \\
\hline Std. Deviation & &
\end{tabular}

Results in table show decrease of portfolio quality mean rank in period from September till January. In September career education activities and portfolio draw student's interest as new part of education. In October students find that regular work on portfolio is hard and interest decrease. In November company representatives visit school and student positively react to portfolio tasks. In December students visited company and positively refer after visit but find that visit documentation and presentation in portfolio demand a lot of knowledge and 
skills. In January students was enthusiastic in visit presentation preparation for company and work in small groups. February task was innovative project ideas generation and students was enthusiastic on task completion. Still a large number of students were not able to complete portfolio tasks.

To ensure about school, company and municipality collaboration process career counselors were interviewed. 19 counselors answer to two questions: Positive effects of school, company and municipality collaboration observed; Difficulties in school, company and municipality collaboration observed?

Summary of counselor's interview:

1. Positive effects of school, company and municipality collaboration:

- Those students who are actively participated in program began to understand the importance of career management skills;

- Students positively refer to offered career information resources and opportunities for self-directed profession investigation;

- Are regularly held group and individual career counseling;

- Career counselor regularly collected and placed in the e-environment indicators of student's progress;

- Implementation of e-environment for career education and counseling;

- Teachers start to understand the importance of career education;

- Successful collaboration with companies;

- "Second chance" schools students have an opportunity to meet employers;

- Students were introduced with training programs offered by companies;

- Collaboration with companies gives opportunity for student's innovative projects development;

- Municipality support student's career education activities.

2. Difficulties in school, company and municipality collaboration:

- Students need motivation for task completion, because not all students can see connection between career education and portfolio tasks and their own career perspective;

- Students are too busy and career education need extra time;

- Students are low skilled and need to assistance in career management skills portfolio completion;

- Students have a difficulties to understand written information and they dislike write their own thoughts, but prefer multiple choice questions with offered answers;

- Students prefer work in group sessions but not independently in internet classroom;

- Students have a difficulties keep attention to long term tasks;

- Schools need to improve computer equipment and internet access;

- Teachers not always ready to collaborate for career education integration in learning process at school;

- Small number of companies which are ready for collaboration with schools;

- Career education should be integrated in municipality and school plans; 
- Municipality, schools and companies should collaborate for student's employment programs provision in summer.

In this article data of career education program evaluated in middle of implementation and therefore not all career education activities realized.

\section{Conclusions}

Analysis of recent situation in career education in Latvia leads to conclusion that practical integration in school should be strengthened. Facilitation of students (13-25 years old) career choice and learning for working life is possible through school, company and municipality collaboration in career education. Were a three interrelated stages of implementation of career education model - career education, career counseling and case management. Main results of empirical study evidence for:

1. Results show that $22,2 \%$ of students did not think about future plans and 25 $\%$ don't know what they do after graduate school. Results evidence for career guidance in school is necessary.

2. Results evidence for positive correlation between student's future plans and quality of career management skills portfolio $(\mathrm{r}=346)$. These results prove the idea of using portfolio in career education. Portfolio quality indicated a level of student career management skills.

3. For integration of career education in school learning process career counselor, class teacher and subject teacher collaboration is necessary.

\section{Bibliography}

1. Education, Audiovisual and Culture Executive Agency. (2012). Entrepreneurship Education at School in Europe. National Strategies, Curricula and Learning Outcomes. Retrieved 06.03.2013, from European Commision. Education, Audiovisual and Culture Executive Agency: http://eacea.ec.europa.eu/education/eurydice/documents/thematic reports/135EN.pdf

2. European Commision. (2012). Developing Key Competencies in school in Europe: Challanges and opportunities for police. Retrieved 06.03.2013, from European

3. Commission/EACEA/Eurydice: http://eacea.ec.europa.eu/education/eurydice/documents/thematic reports/145EN.pdf

4. Education, Youth and Culture Council of the European Union. (2008). Council Resolution on better integrating lifelong guidance into lifelong learning strategies. Retrieved 03.03.2013, from Council of the European Union: http://www.consilium.europa.eu/ueDocs/cms_Data/docs/pressData/en/educ/104236.pdf

5. European Commision. (2010, 02 04). New skills for new jobs. Retrieved 04 26, 2010, from European Commision. Education and Training: http://ec.europa.eu/education/news/news2122_en.htm

6. European Commission. (2001, 11 21). Making a European Area of Lifelong Learning a Reality. Retrieved 03 11, 2010, from Summaries of EU legislation: http://eurlex.europa.eu/LexUriServ/LexUriServ.do?uri=CELEX:52001DC0678:EN:HTML 
7. Faure, E. (1972). Learning to be: The world of education today and tomorrow. Paris: UNESCO.

8. Latvian State Education Development Agency. (2012). Guidance System in Latvia. Retrieved 03.03.2013, from Latvian State Education Development Agency: http://www.viaa.gov.lv/files/news/1808/guidance_system_en.pdf

9. Strods, G. (2003). Studentu pašizglītība studiju procesā.[Students self-directed learning in university]. Personality. Time. Communication. International scientific conference (pp. 122-131). Rezekne: Rēzeknes Augstskola.

10. Strods, G. (2006). Studentu pašizglītības pedagoǵiskie aspekti. [Educational aspects of students self-directed learning]. Society. Integration. Education (pp. 93-105). Rezekne: Rezekne University.

11. Strods, G. (2012). Promotion of Students self-directed learning in university. Society. Integration. Education (pp. 112-120). Rezekne: Rezekne University.

12. Teddlie, CH. \& Tashakkori, A. (2006). A general typology of research designs featuring mixed methods. Research in the schools, 13 (1), 12-28.

13. University of Latvia. (2011). Atbalsta programmu izstrāde un īstenošana sociālās atstumtības riskam pakḷauto jauniešu atbalsta sistēmas izveidei. [Development and implementation of the support programs for establishing the support system for the young people under the exclusion risk]. Retrieved 03.03.2013, from University of Latvia: http://www.atbalsts.lu.lv/lv/projekta-rezultati/visparigi/project-information

\begin{tabular}{|r|l|}
\hline Gunārs Strods, & Rezekne Higher Educational Institution, \\
assistant professor & Atbrivosanas aleja 115, Rezekne, \\
& Latvia, LV 4601 \\
& E-mail: gunars@ ru.lv \\
\hline
\end{tabular}

